\title{
Enterotoxigenic Escherichia coli Infections
}

\author{
James M. Fleckenstein ${ }^{1,2}$ - F. Matthew Kuhlmann ${ }^{1}$ \\ Published online: 4 March 2019 \\ (C) Springer Science+Business Media, LLC, part of Springer Nature 2019
}

\begin{abstract}
Purpose of Review Review recent developments pertaining to the epidemiology, molecular pathogenesis, and sequelae of enterotoxigenic Escherichia coli (ETEC) infections in addition to discussion of challenges for vaccinology.

Recent Findings ETEC are a major cause of diarrheal illness in resource poor areas of the world where they contribute to unacceptable morbidity and continued mortality particularly among young children; yet, precise epidemiologic estimates of their contribution to death and chronic disease have been difficult to obtain. Although most pathogenesis studies, and consequently vaccine development have focused intensively on canonical antigens, more recently identified molecules unique to the ETEC pathovar may inform our understanding of ETEC virulence, and the approach to broadly protective vaccines.

Summary ETEC undeniably continue to have a substantial impact on global health; however, further studies are needed to clarify the true impact of these infections, particularly in regions where access to care may be limited. Likewise, our present understanding of the relationship of ETEC infection to non-diarrheal sequelae is presently limited, and additional effort will be required to achieve a mechanistic understanding of these diseases and to fulfill Koch's postulates on a molecular level. Precise elucidation of the role played by novel virulence factors, the global burden of acute illness, and the contribution of these pathogens and/or their toxins to non-diarrheal morbidity remain important imperatives.
\end{abstract}

Keywords Enterotoxigenic E. coli (ETEC) · Diarrhea · Tropical sprue · Environmental enteric dysfunction · Vaccine

\section{Introduction}

EnterotoxigenicE. coli (ETEC) are a pathogenic variant or pathovar of $E$. coli defined by production of diarrheagenic heat-labile (LT) and heat-stable (ST) enterotoxins. These bacteria, originally identified as a cause of cholera-like watery diarrhea nearly five decades ago [1, 2], have persisted as a major global health threat, particularly among young children in resource-limited areas of the world. Here, it is estimated that children under the age

This article is part of the Topical Collection on Intra-Abdominal Infections, Hepatitis and Gastroenteritis

James M. Fleckenstein

jflecken@wustl.edu

1 Department of Medicine, Division of Infectious Diseases, Washington University School of Medicine, 660 South Euclid Avenue, Saint Louis, MO 63110, USA

2 Medicine Service, Veterans Affairs Medical Center, Saint Louis, MO, USA of five suffer over a billion cases of diarrheal illness annually [3], with ETEC alone linked to hundreds of millions of episodes of diarrhea [4]. While the overall mortality from diarrheal diseases appears to have decreased considerably over the past several decades, ETEC remains a leading cause of death among young children [5, 6•]. The attack rate for ETEC illness appears to be highest during the first 2 years of life in endemic areas [7], with substantial declines thereafter suggesting that protective immunity develops following infection. Notably, these pathogens are thought to cause substantial disease as well as tens of thousands of deaths in older children, adolescents, and adults in areas of high endemicity for diarrheal illness including Africa and Asia [8].

\section{Challenges in Defining the Global Burden of ETEC}

Enterotoxigenic E. coli are ubiquitously distributed throughout all resource poor areas of the world. While ETEC are 
clearly recognized as a globally important cause of diarrheal illness, regional estimates of death and morbidity associated with ETEC and other enteric pathogens vary widely in recent large epidemiologic assessments in LMIC [4, 9, 10•]. An accurate global accounting of the diarrheal disease burden has generally been confounded by the fact that assessment of the attributable mortality and morbidity, particularly at the level of individual enteric pathogens, may be most difficult in regions with limited infrastructure and high endemicity [4, 11••, 12, 13]. Multiple factors contribute to the considerable variability in disease estimates reported in these studies including the definition of diarrhea, local disease prevalence, access to care, and methods used for detecting enteric pathogens [13-15]. Indeed, use of molecular techniques such as quantitative PCR to attribute causation to individual pathovars leads to 1.5-fold increase in ETEC pathogen-specific disease burden relative to asymptomatic control subjects [6•]. Neither the burden of diarrheal illness nor access to life-saving treatment is equitably distributed, and progress in implementing preventative measures has lagged in some high prevalence areas [16]. Despite apparent overall declines in diarrheal mortality, the incidence of diarrheal infections and their associated morbidity $[15,17]$ has continued unabated.

ETEC is without question one of the most common causes of diarrheal illness in travelers and in military deployed to endemic areas [18-21]. In 11 separate studies performed between 2010 and 2016, ETEC was the most common pathogen identified in traveler's diarrhea (TD) accounting for an average of $42 \%$ and $28 \%$ of cases in travelers to Latin America and Asia, respectively [22].

Although ETEC infections in travelers are typically selflimited, antibiotics can hasten the resolution of symptoms. Unfortunately, these and other pathogens associated with TD have become increasingly resistant to antibiotics [23-25], and a number of recent studies have expressed concerns about the potential for acquisition and subsequent carriage [26] of multidrug-resistant Enterobacteriaceae including E. coli [27] during travel and through the selective pressure of antibiotics for treatment or prophylaxis.

Interestingly, with the advent of molecular testing, ETEC have increasingly been identified in both sporadic cases, and in diarrheal outbreaks in the USA. Nevertheless, as ETEC cannot be distinguished from commensal E. coli or other pathovars without molecular testing, they often go unrecognized unless there is a recognized cluster of cases that leads to testing in specialized public health laboratories [28-34]. Notably, application of molecular techniques to pathogen identification in diarrheal stool demonstrated that ETEC were as common as most other enteric bacterial pathogens [35••], suggesting that these pathogens may be commonly missed by culture-dependent methodologies in common use in clinical microbiology laboratories.

\section{ETEC Molecular Pathogenesis}

\section{Cellular Action of Enterotoxins}

Genes encoding heat-labile and heat-stable toxins [36-40] are encoded on virulence plasmids and were among the first bacterial virulence factors to be cloned, sequenced, and characterized on a molecular level. Indeed, these early findings form the basis of the molecular detection assays presently in use [6•]. LT shares substantial homology with cholera toxin (CT), and like CT, LT is a heteroheximer composed of a single A subunit and a pentameric B subunit. LT binds via the pentamer to GM-1 ganglioside on the surface of intestinal epithelial cells, followed by uptake of the toxin, and liberation of the biologically active A subunit. LT and CT belong to a large family of bacterial ADP-ribosylating toxins which act by transferring ADP-ribose to target substrate molecules [41]. LT-A catalyzes the ADP-ribosylation of GS $\alpha$ leading to formation of an ADP-ribose-GS $\alpha$-GTP complex that activates adenylate cyclase leading to formation of cAMP.

ST is found in two different forms: STh and STp. Both ST molecules are small cysteine-rich peptides of 18-19 amino acids that share homology with native endogenous peptides, guanylin and uroguanylin, and all four of these molecules bind to guanylate cyclase $\mathrm{C}$ (GC-C) on the surface of intestinal epithelia [42••], leading to the production of cGMP.

Both cyclic nucleotides cAMP and cGMP activate intracellular protein kinases that lead to phosphorylation and alteration of ion channels including the cystic fibrosis transmembrane regulator (CFTR) chloride channel, and inhibition of the $\mathrm{Na}+\mathrm{H}+$ exchanger NHE3 [43], the net effect of which is the accumulation of salt and water in the intestinal lumen leading to watery diarrhea.

ETEC secreting any one of the known toxins rely on chromosomally encoded secretion systems for export. LT is secreted by a type 2 secretion system [44] similar to that responsible for export of CT by $V$. cholerae, while both STh and STp are secreted via the TolC outer membrane efflux protein $[45,46]$.

\section{Colonization Factors}

ETEC express a broad array of plasmid encoded molecules or structures collectively known as colonization factors (CFs) that facilitate intestinal colonization. The first of these, CFA/ I, was discovered shortly after the discovery of ETEC as a cause of diarrheal illness $[47,48]$. Since that time, more than 20 antigenically distinct CFs have been characterized, and novel CFs continue to emerge as whole genome sequencing (WGS) is applied to strains lacking previously characterized antigens [49]. Although anywhere from 30 to $50 \%$ of isolates in prior studies lacked an identifiable CF $[50,51]$ using CFspecific monoclonal antibodies for antigen detection, WGS analysis of strains previously characterized as lacking a 
known CF suggest that most of the corresponding genomes encode novel or previously uncharacterized CFs [52].

\section{Non-canonical Virulence Factors}

Although most studies of ETEC pathogenesis to date have centered around the classical plasmid-encoded antigens that were discovered nearly five decades ago, more recent studies suggest that the molecular pathogenesis of these organisms is significantly more complex than had been previously appreciated. Interestingly, enthusiasm for targeting CFs in vaccines was engendered by examination of a plasmid cured strain of ETEC which had lost the CFA/I virulence plasmid, as this isolate, H10407-P, did not cause diarrhea in human volunteer challenge studies while the parent strain isolated from a case of choleralike illness predictably caused voluminous diarrhea [53].

More recent studies have demonstrated, however, that in addition to CFA/I, this large plasmid carries at least two additional virulence loci, initially discovered by transposon mutagenesis in a search for novel secreted antigens. The eatA gene encodes EatA [54], a member of the serine protease autotransporter of the Enterobacteriaceae (SPATE) family, while the etpBAC locus encodes the EtpA extracellular adhesin, the EtpB PORTA domain outer membrane transport protein, and the EtpC glycosyltransferase [55].

The secreted EatA passenger domain $(\sim 110 \mathrm{kD})$ contains a canonical serine protease motif and is highly immunogenic. Recent data suggests that EatA may enhance ETEC access to intestinal epithelial cells by degrading MUC2 [56], the major mucin secreted by intestinal goblet cells. In addition to degradation of MUC2, EatA also degrades EtpA, potentially preventing the accumulation of the adhesin [57].

EtpA is a large $(\sim 170 \mathrm{kD})$ glycoprotein that is secreted by ETEC. Once secreted, EtpA appears to function as a molecular bridge connecting the ends of ETEC flagella [58] with Nacetylgalactosamine (GalNAc) containing glycans expressed on intestinal mucosal surfaces [59]. Although GalNAc is abundant in intestinal mucin [60], the EtpA lectin has the highest affinity for GalNAc presented as the terminal sugar on A blood group glycans. Because these glycans are expressed on intestinal epithelial cells, EtpA-mediated interactions preferentially promote bacterial adhesion to brush border glycans and consequently toxin delivery to small intestinal enterocytes from A blood group individuals. These blood group-dependent interactions may translate to the more severe disease among A blood group experimental human challenge subjects [61] and naturally infected children in endemic regions [7].

While all of the pathovar-specific virulence molecules for ETEC described to date are encoded on plasmids, it is apparent that these act in concert [62] with highly conserved chromosomally encoded features that are part of $E$. coli core genomes. These include type 1 fimbriae [63], the EaeH adhesin [64], surface expressed autotransporter proteins [65] and the
YghJ metalloprotease [66]. The coordinate interaction of these core and pathovar-specific features ultimately drive efficient pathogen-host interactions required for optimal delivery of ETEC toxins [67]. ETEC are typically identified by molecular testing for their toxins. Nevertheless, it is clear that the pathogen virulence traits and host features associated with more severe cholera like disease [68] are still being defined [61]. Presently available molecular tools, including whole genome sequencing of pathogens, have also served to illustrate that ETEC is not a static pathovar and that these pathogens are likely part of a dynamic and ongoing admixture of potential virulence genes $[69,70]$.

\section{Association of ETEC with Post-diarrheal Sequelae}

A number of chronic sequelae have been associated with diarrheal illness caused by a variety of enteropathogens including pathogenic $E$. coli. While studies are ongoing which attempt to link specific pathogens to these sequelae [71, 72], in general the pathogenesis of these post infectious phenomena remains very poorly understood.

\section{Post-infectious Irritable Bowel Syndrome}

It is estimated that up to $3 \%$ of individuals with traveler's diarrhea have protracted symptoms that last more than 1 month [73] and that post-infectious IBS occurs in an estimated 10 $30 \%$ of patients following acute gastroenteritis [74-78]. One study of more than 500 travelers in Israel documented a 5-fold increase in risk for IBS in those who developed diarrhea relative to those who remained asymptomatic [79]. Given the predominance of enterotoxigenic $E$. coli as a cause of traveler's diarrhea (TD), it is not altogether surprising that at least one study has linked ETEC to the development of IBS. Intriguingly, however, the association was only with LTproducing ETEC, but not with other ETEC [80].

Although it has been suggested that post-infectious IBS generally carries a better prognosis than idiopathic IBS [81, 82], this has not been validated in subsequent studies [83]. IBS associated infectious with diarrheal was associated with a higher frequency of diarrheal illness, however long-term prognosis did not differ significantly from idiopathic IBS in that less than half of patients in either group had resolution of symptoms.

\section{Post-infectious Malabsorption Syndromes, Growth Stunting, and Cognitive Impairment}

\section{Tropical Sprue and Environmental Enteric Dysfunction}

The first descriptions of individuals with malabsorption syndromes in the tropics date back more than 250 years [84], and 
Manson, working in China later referred to similar ailments as "tropical sprue" [85]. Tropical sprue has since been synonymous with post-infectious malabsorption syndromes, potentially caused by a variety of pathogens [86], and is characterized by blunting of the small intestinal villi, persistent diarrhea, steatorrhea, and folate and B12 deficiency [87-89]. Tropical sprue is clearly described as a sequela of diarrheal illness in travelers and expatriates $[88,89]$. Interestingly, studies of Peace Corps volunteers traveling to India or Pakistan in the 1970s, all of whom developed diarrhea during an 18-24month tour (with $90 \%$ having had diarrhea $\geq$ monthly), demonstrated a high incidence of weight loss, as well as abnormal jejunal architecture and malabsorption that reversed on return to the USA [90]. Yet, despite the predominance of ETEC as a major cause of traveler's diarrhea, and the repeated isolation of toxin-producing $E$. coli from small intestinal aspirates of patients with tropical sprue [91-93], most of these studies were done prior the advent of molecular techniques in use today. Although a clinical response to antibiotics in patients with tropical sprue also supports a possible bacterial etiology [86, 94], molecular Koch's postulates [95] clearly establishing a direct link between ETEC and the development of tropical sprue are presently lacking.

Some have speculated that tropical sprue may essentially represent part of a spectrum of illness similar to tropical enteropathy $[96,97]$ or environmental enteric dysfunction $[98$, 99] that is frequently associated with diarrheal pathogens among young children in developing countries that results in altered intestinal absorption, growth faltering, poor response to oral vaccines, and cognitive impairment [100-102]. Observations of malnutrition or kwashiorkor following acute diarrheal illness in developing countries are longstanding [103]. Cohort studies of children followed in highly endemic areas of Bangladesh demonstrated that they were more likely to be underweight [104] and/or growth stunted following diarrhea caused by ETEC [7]. Conversely, malnourished children also appear to be at significantly higher risk for diarrheal illness [105], and for development of protracted diarrhea caused by ETEC [104].

ETEC are frequently found in the stools of young children in the developing world without diarrhea, a phenomenon that has significantly confounded [11••] recent estimates of morbidity and mortality attributable to these pathogens [4]. Nevertheless, some studies have suggested that carriage of ETEC and other pathogens may be sufficient to drive changes associated with enteropathy and malnutrition [106••, 107]. Likewise, recent studies suggest that cognitive impairment linked to diarrheal pathogens is associated with enteropathogen carriage even in the absence of diarrheal illness again suggesting perhaps that subclinical infections could contribute to enteropathy [108]. Clearly, the relationship of malnutrition and stunting to infection with a number of enteropathogens is complex and the recent demonstration of small intestinal overgrowth with orpharyngeal microbiota may further complicate attempts to link these sequelae to specific pathogens [109]. Notably, however, these studies also demonstrated an increase in possible enteropathogenic genera defined as E. coli/Shigella by 16S rRNA sequencing, suggesting that stunting represents the end result of a number of insults to small intestinal epithelia.

\section{Challenges for ETEC Vaccinology}

ETEC vaccines in development have been reviewed extensively $[110 \bullet, 111,112]$; therefore, here, we focus primarily on the challenges that need to be surmounted in vaccine development. Currently, there are no vaccines for ETEC that are licensed in the USA. Dukoral (Valvena, Sweden AB) is an oral, whole cell killed (WC) Vibrio cholera O1 vaccine containing recombinant cholera toxin B subunit (rBS), available in Canada and Sweden for prevention of traveler's diarrhea, but not the USA. In large-scale field trials (involving nearly 50,000 vaccinees) comparing WC to WC-rBS, recipients of the vaccine containing cholera toxin $\mathrm{B}$ subunit experienced substantial short-term protection with a protective efficacy (PE) of $86 \%$ against severe, life-threatening diarrhea caused by LT ETEC [113]. Although it was anticipated that this vaccine would afford some protection against LT-ETEC due to the considerable homology between cholera toxin and LT, the vaccine also offered short duration protection against ETEC that also produced ST (LT/ST, PE 73\%). The short protection afforded by this vaccine led to several smaller studies in travelers that subsequently demonstrated modest $\mathrm{PE}$ against ETEC diarrhea ranging from 28 to $50 \%$ [114-116].

Clearly, additional effort will be needed to engender the broad-based, long-term protection needed for individuals in developing countries. One major hurdle that ETEC vaccines have had to overcome is the underlying plasticity of $E$. coli genomes [117]. The promiscuous adaptation of colonization factors [50], with more than 20 antigenically distinct antigens described thus far [118], illustrates the need for a multivalent approach that can target the most highly conserved molecules. In an attempt to develop protective vaccines, most formulations to reach clinical trials have embraced this approach by incorporating a combination of the most common $\mathrm{CF} / \mathrm{CS}$ antigens with mutant versions of LT [119, 120].

Data emerging from genome analyses indicate that some of the more recently described virulence factors including EtpA and EatA are conserved across the ETEC pathovar [121, 122], perhaps providing targets that could complement canonical approaches and broad-based protection. Indeed, recent immunoproteome analysis of human volunteer samples using ETEC protein microarrays indicates that these highly immunogenic molecules are among a relatively small number of pathovar specific antigens recognized during infection [123], 
findings that can collectively direct antigen selection in rational vaccine design.

Given that toxoids afford substantial protection against other important toxigenic mucosal pathogens including pertussis [124, 125], combining highly conserved antigens with LT [126] and ST [42••] toxoids in development could accelerate deployment of a broadly protective formulation [127-129]. Mutant versions of LT such as LT(RL211A/L211A) or dmLT appear to be both safe and remarkably effective as mucosal adjuvants, and LT alone was shown previously to afford substantial protection against ETEC that produced only LT [130].

From a feasibility standpoint, a vaccine that targets other enteric pathogens in a combination vaccine, in particular Shigella in addition to ETEC, may be required to secure the necessary development resources [13, 14••, 131]. ETEC and Shigella along with Campylobacter are responsible for the majority of serious bacterial diarrhea in LMIC regions. Therefore, polyvalent combination vaccines encompassing antigens from ETEC and other pathogens could yield a practical multi-pathogen diarrheal disease vaccine [131-134].

\section{Summary}

Enterotoxigenic E. coli are an important cause of diarrheal illness in LMIC areas of the world where they place a particular burden on the health of young children. Additional efforts to define the contribution of ETEC to non-diarrheal sequelae have increased in importance as deaths from acute diarrheal illness from all causes have declined over the past several decades while both the incidence of infectious diarrhea and morbidity associated with these pathogens continue unabated. Ongoing pathogenesis studies that elucidate the role of recently identified virulence molecules, and reexamine the cellular impact of the established toxins can inform and prioritize approaches to vaccine development for these pathogens of global importance.

Funding Information Work reported in this publication was supported by PATH; funding from National Institute of Allergy and Infectious Diseases (NIAID) of the National Institutes of Health (NIH) under Award Numbers R01AI089894 (jmf), R01AI126887 (jmf), K23 AI130389 (fmk), the Washington University Institute of Clinical and Translational Sciences grant UL1 TR000448 from the National Center for Advancing Translational Sciences (NCATS) of the NIH, and the Department of Veterans Affairs (5I01BX001469, jmf). The content is solely the responsibility of the authors and does not necessarily represent the official views of the NIH, NIAID, NCATS, the Department of Veterans Affairs, or PATH.

\section{Compliance with Ethical Standards}

Conflict of Interest James M. Fleckenstein and F. Matthew Kuhlmann declare that they have no conflict of interest.
Human and Animal Rights and Informed Consent This article does not contain any studies with human or animal subjects performed by any of the authors. Informed consent was taken from patients prior to enrollment.

Publisher's Note Springer Nature remains neutral with regard to jurisdictional claims in published maps and institutional affiliations.

\section{References}

Papers of particular interest, published recently, have been highlighted as:

- Of importance

•- Of major importance

1. Sack RB, Gorbach SL, Banwell JG, Jacobs B, Chatterjee BD, Mitra RC. Enterotoxigenic Escherichia coli isolated from patients with severe cholera-like disease. J Infect Dis. 1971;123(4):37885.

2. Sack RB. The discovery of cholera - like enterotoxins produced by Escherichia coli causing secretory diarrhoea in humans. Indian J Med Res. 2011;133(2):171-80.

3. Collaborators GBDDD. Estimates of global, regional, and national morbidity, mortality, and aetiologies of diarrhoeal diseases: a systematic analysis for the global burden of disease study 2015 . Lancet Infect Dis. 2017;17(9):909-48. https://doi.org/10.1016/ S1473-3099(17)30276-1.

4. Khalil IA, Troeger C, Blacker BF, Rao PC, Brown A, Atherly DE, et al. Morbidity and mortality due to shigella and enterotoxigenic Escherichia coli diarrhoea: the global burden of disease study 1990-2016. Lancet Infect Dis. 2018;18:1229-40. https://doi.org/ 10.1016/S1473-3099(18)30475-4.

5. Kotloff KL, Nataro JP, Blackwelder WC, Nasrin D, Farag TH, Panchalingam S, et al. Burden and aetiology of diarrhoeal disease in infants and young children in developing countries (the global enteric multicenter study, GEMS): a prospective, case-control study. Lancet. 2013;382(9888):209-22. https://doi.org/10.1016/ S0140-6736(13)60844-2.

6. Liu J, Platts-Mills JA, Juma J, Kabir F, Nkeze J, Okoi C, et al. Use of quantitative molecular diagnostic methods to identify causes of diarrhoea in children: a reanalysis of the GEMS case-control study. Lancet. 2016;388(10051):1291301. https://doi.org/10.1016/S0140-6736(16)31529-X ETEC identified more frequently when molecular methods are employed.

7. Qadri F, Saha A, Ahmed T, Al Tarique A, Begum YA, Svennerholm AM. Disease burden due to enterotoxigenic Escherichia coli in the first 2 years of life in an urban community in Bangladesh. Infect Immun. 2007;75(8):3961-8. https://doi.org/ 10.1128/IAI.00459-07.

8. Lamberti LM, Bourgeois AL, Fischer Walker CL, Black RE, Sack D. Estimating diarrheal illness and deaths attributable to Shigellae and enterotoxigenic Escherichia coli among older children, adolescents, and adults in South Asia and Africa. PLoS Negl Trop Dis. 2014;8(2):e2705. https://doi.org/10.1371/journal.pntd. 0002705 .

9. Collaborators GBDDD. Estimates of the global, regional, and national morbidity, mortality, and aetiologies of diarrhoea in 195 countries: a systematic analysis for the Global Burden of Disease Study 2016. Lancet Infect Dis 2018. https://doi.org/10. 1016/S1473-3099(18)30362-1, Estimates of the global, regional, and national morbidity, mortality, and aetiologies of diarrhoea in 
195 countries: a systematic analysis for the Global Burden of Disease Study 2016, 18, 1228.

10. Reiner RC Jr, Graetz N, Casey DC, Troeger C, Garcia GM, Mosser JF, et al. Variation in Childhood Diarrheal Morbidity and Mortality in Africa, 2000-2015. N Engl J Med. 2018;379(12):1128-38. https://doi.org/10.1056/ NEJMoa1716766 Detailed estimates of geographic distribution of diarrheal disease demonstrating that burden is highly concentrated in some regions.

11.• Lanata CF, Black RE. Estimating the true burden of an enteric pathogen: enterotoxigenic Escherichia coli and Shigella spp. Lancet Infect Dis. 2018;18:1165-6. https://doi.org/10.1016/ S1473-3099(18)30546-2 Provides important perspecitives on limitations of current global burden of disease estimates.

12. Gill CJ, Thea DM, Hibberd P. Diarrhoeal disease trends in the GBD 2015 study: optimism tempered by scepticism. Lancet Infect Dis. 2017;17(9):884-5. https://doi.org/10.1016/S14733099(17)30336-5.

13. Hosangadi D, Smith PG, Kaslow DC, Giersing BK, Who E, Shigella Vaccine Consultation Expert G. WHO consultation on ETEC and Shigella burden of disease, Geneva, 6-7th April 2017: Meeting report. Vaccine 2018. https://doi.org/10.1016/j. vaccine.2017.10.011.

14.• Hosangadi D, Smith PG, Giersing BK. Considerations for using ETEC and Shigella disease burden estimates to guide vaccine development strategy. Vaccine. 2017. https://doi.org/10.1016/j. vaccine.2017.09.083 Concise summary comparing disease burden estimates.

15. Kotloff KL. The burden and etiology of diarrheal illness in developing countries. Pediatr Clin N Am. 2017;64(4):799-814. https:// doi.org/10.1016/j.pcl.2017.03.006.

16. International Vaccine Access Center (IVAC) JHSoPH. Pneumonia and Diarrhea Progress Report 2018. 2018.

17. Petri WA Jr, Miller M, Binder HJ, Levine MM, Dillingham R, Guerrant RL. Enteric infections, diarrhea, and their impact on function and development. J Clin Invest. 2008;118(4):1277-90. https://doi.org/10.1172/JCI34005.

18. Riddle MS, Sanders JW, Putnam SD, Tribble DR. Incidence, etiology, and impact of diarrhea among long-term travelers (US military and similar populations): a systematic review. Am J Trop Med Hyg. 2006;74(5):891-900.

19. Shah N, DuPont HL, Ramsey DJ. Global etiology of travelers' diarrhea: systematic review from 1973 to the present. Am J Trop Med Hyg. 2009;80(4):609-14.

20. Hameed JM, McCaffrey RL, McCoy A, Brannock T, Martin GJ, Scouten WT, et al. Incidence, etiology and risk factors for Travelers' diarrhea during a hospital ship-based military humanitarian Mission: continuing promise 2011. PLoS One. 2016;11(5): e0154830. https://doi.org/10.1371/journal.pone.0154830.

21. Steffen R, Hill DR, DuPont HL. Traveler's diarrhea: a clinical review. JAMA. 2015;313(1):71-80. https://doi.org/10.1001/ jama.2014.17006.

22. Jiang ZD, DuPont HL. Etiology of travellers' diarrhea. J Travel Med. 2017;24(suppl_1):S13-S6. https://doi.org/10.1093/jtm/ tax003

23. Tribble DR. Resistant pathogens as causes of traveller's diarrhea globally and impact(s) on treatment failure and recommendations. J Travel Med. 2017;24(suppl_1):S6-S12. https://doi.org/10.1093/ $\mathrm{jtm} / \mathrm{taw} 090$.

24. Margulieux KR, Srijan A, Ruekit S, Nobthai P, Poramathikul K, Pandey P, et al. Extended-spectrum beta-lactamase prevalence and virulence factor characterization of enterotoxigenic Escherichia coli responsible for acute diarrhea in Nepal from 2001 to 2016. Antimicrob Resist Infect Control. 2018;7:87. https://doi.org/10. 1186/s13756-018-0377-2.
25. Riddle MS, Connor P, Fraser J, Porter CK, Swierczewski B, Hutley EJ, et al. Trial evaluating ambulatory therapy of Travelers' diarrhea (TrEAT TD) study: a randomized controlled trial comparing 3 single-dose antibiotic regimens with Loperamide. Clin Infect Dis. 2017;65(12):2008-17. https://doi. org/10.1093/cid/cix693.

26. Ruppe E, Armand-Lefevre L, Estellat C, Consigny PH, El Mniai A, Boussadia $Y$, et al. High rate of acquisition but Short duration of carriage of multidrug-resistant Enterobacteriaceae after travel to the tropics. Clin Infect Dis. 2015;61(4):593-600. https://doi.org/ 10.1093/cid/civ333.

27. Kennedy K, Collignon P. Colonisation with Escherichia coli resistant to "critically important" antibiotics: a high risk for international travellers. Eur J Clin Microbiol Infect Dis. 2010;29(12):1501-6. https://doi.org/10.1007/s10096-010-1031-y.

28. Yoder JS, Cesario S, Plotkin V, Ma X, Kelly-Shannon K, Dworkin MS. Outbreak of enterotoxigenic Escherichia coli infection with an unusually long duration of illness. Clin Infect Dis. 2006;42(11): 1513-7.

29. Naimi TS, Wicklund JH, Olsen SJ, Krause G, Wells JG, Bartkus $\mathrm{JM}$, et al. Concurrent outbreaks of Shigella sonnei and enterotoxigenic Escherichia coli infections associated with parsley: implications for surveillance and control of foodborne illness. J Food Prot. 2003;66(4):535-41.

30. Beatty ME, Bopp CA, Wells JG, Greene KD, Puhr ND, Mintz ED. Enterotoxin-producing Escherichia coli O169:H41. United States Emerg Infect Dis. 2004;10(3):518-21. https://doi.org/10.3201/ eid1003.030268.

31. Beatty ME, Adcock PM, Smith SW, Quinlan K, Kamimoto LA, Rowe SY, et al. Epidemic diarrhea due to enterotoxigenic Escherichia coli. Clin Infect Dis. 2006;42(3):329-34.

32. Roels TH, Proctor ME, Robinson LC, Hulbert K, Bopp CA, Davis JP. Clinical features of infections due to Escherichia coli producing heat-stable toxin during an outbreak in Wisconsin: a rarely suspected cause of diarrhea in the United States. Clin Infect Dis. 1998;26(4):898-902.

33. Devasia RA, Jones TF, Ward J, Stafford L, Hardin H, Bopp C, et al. Endemically acquired foodborne outbreak of enterotoxinproducing Escherichia coli serotype O169:H41. Am J Med. 2006;119(2):168 e7-10.

34. Jain S, Chen L, Dechet A, Hertz AT, Brus DL, Hanley K, et al. An outbreak of enterotoxigenic Escherichia coli associated with sushi restaurants in Nevada, 2004. Clin Infect Dis. 2008;47(1):1-7.

35.• Medus C, Besser JM, Juni BA, Koziol B, Lappi V, Smith KE, et al. Long-Term Sentinel Surveillance for Enterotoxigenic Escherichia coli and Non-O157 Shiga Toxin-Producing E. coli in Minnesota. Open Forum Infect Dis. 2016;3(1):ofw003. https://doi.org/10. 1093/ofid/ofw003 In two sites in Minnesota ETEC was surprisingly as common as other enteric pathogens when molcular methods were employed for protection.

36. So M, Boyer HW, Betlach M, Falkow S. Molecular cloning of an Escherichia coli plasmid determinant than encodes for the production of heat-stable enterotoxin. J Bacteriol. 1976;128(1):463-72.

37. So M, Dallas WS, Falkow S. Characterization of an Escherichia coli plasmid encoding for synthesis of heat-labile toxin: molecular cloning of the toxin determinant. Infect Immun. 1978;21(2):40511.

38. Moseley SL, Samadpour-Motalebi M, Falkow S. Plasmid association and nucleotide sequence relationships of two genes encoding heat-stable enterotoxin production in Escherichia coli H-10407. J Bacteriol. 1983;156(1):441-3.

39. Gyles C, So M, Falkow S. The enterotoxin plasmids of Escherichia coli. J Infect Dis. 1974;130(1):40-9.

40. Dallas WS, Falkow S. Amino acid sequence homology between cholera toxin and Escherichia coli heat-labile toxin. Nature. 1980;288(5790):499-501. 
41. Simon NC, Aktories K, Barbieri JT. Novel bacterial ADPribosylating toxins: structure and function. Nat Rev Microbiol. 2014;12(9):599-611. https://doi.org/10.1038/nrmicro3310.

42.• Taxt AM, Diaz Y, Aasland R, Clements JD, Nataro JP, Sommerfelt $\mathrm{H}$, et al. Towards Rational Design of a Toxoid Vaccine against the Heat-Stable Toxin of Escherichia coli. Infect Immun. 2016;84(4): 1239-49. https://doi.org/10.1128/IAI.01225-15 Outlines a potential strategy for development of heat-stable toxoids.

43. Chen T, Kocinsky HS, Cha B, Murtazina R, Yang J, Tse CM, et al. Cyclic GMP kinase II (cGKII) inhibits NHE3 by altering its trafficking and phosphorylating NHE3 at three required sites: identification of a multifunctional phosphorylation site. J Biol Chem. 2015;290(4):1952-65. https://doi.org/10.1074/jbc.M114.590174.

44. Tauschek M, Gorrell RJ, Strugnell RA, Robins-Browne RM. Identification of a protein secretory pathway for the secretion of heat-labile enterotoxin by an enterotoxigenic strain of Escherichia coli. Proc Natl Acad Sci U S A. 2002;99(10):7066-71.

45. Yamanaka H, Nomura T, Fujii Y, Okamoto K. Need for TolC, an Escherichia coli outer membrane protein, in the secretion of heatstable enterotoxin I across the outer membrane. Microb Pathog. 1998;25(3):111-20. https://doi.org/10.1006/mpat.1998.0211.

46. Zhu Y, Luo Q, Davis SM, Westra C, Vickers TJ, Fleckenstein JM. Molecular Determinants of Enterotoxigenic Escherichia coli Heat-Stable Toxin Secretion and Delivery. Infect Immun. 2018;86(11). https://doi.org/10.1128/IAI.00526-18.

47. Evans DG, Silver RP, Evans DJ Jr, Chase DG, Gorbach SL. Plasmid-controlled colonization factor associated with virulence in Escherichia coli enterotoxigenic for humans. Infect Immun. 1975;12(3):656-67.

48. Evans DG, Evans DJ Jr, Clegg S, Pauley JA. Purification and characterization of the CFA/I antigen of enterotoxigenic Escherichia coli. Infect Immun. 1979;25(2):738-48.

49. Mentzer AV, Tobias J, Wiklund G, Nordqvist S, Aslett M, Dougan $\mathrm{G}$, et al. Identification and characterization of the novel colonization factor CS30 based on whole genome sequencing in enterotoxigenic Escherichia coli (ETEC). Sci Rep. 2017;7(1):12514. https://doi.org/10.1038/s41598-017-12743-3.

50. Isidean SD, Riddle MS, Savarino SJ, Porter CK. A systematic review of ETEC epidemiology focusing on colonization factor and toxin expression. Vaccine. 2011;29(37):6167-78. https://doi. org/10.1016/j.vaccine.2011.06.084.

51. Qadri F, Das SK, Faruque ASG, Fuchs GJ, Albert MJ, Sack RB, et al. Prevalence of toxin types and colonization factors in Enterotoxigenic Escherichia coli isolated during a 2-year period from diarrheal patients in Bangladesh. J Clin Microbiol. 2000;38(1):27-31.

52. Sahl JW, Sistrunk JR, Baby NI, Begum Y, Luo Q, Sheikh A, et al. Insights into enterotoxigenic Escherichia coli diversity in Bangladesh utilizing genomic epidemiology. Sci Rep. 2017;7(1): 3402. https://doi.org/10.1038/s41598-017-03631-x.

53. Satterwhite TK, Evans DG, DuPont HL, Evans DJ Jr. Role of Escherichia coli colonisation factor antigen in acute diarrhoea. Lancet. 1978;2(8082):181-4.

54. Patel SK, Dotson J, Allen KP, Fleckenstein JM. Identification and molecular characterization of EatA, an autotransporter protein of enterotoxigenic Escherichia coli. Infect Immun. 2004;72(3):178694.

55. Fleckenstein JM, Roy K, Fischer JF, Burkitt M. Identification of a two-partner secretion locus of enterotoxigenic Escherichia coli. Infect Immun. 2006;74(4):2245-58.

56. Kumar P, Luo Q, Vickers TJ, Sheikh A, Lewis WG, Fleckenstein JM. EatA, an immunogenic protective antigen of Enterotoxigenic Escherichia coli. Degrades Intestinal Mucin Infect Immun. 2014;82(2):500-8. https://doi.org/10.1128/IAI.01078-13.

57. Roy K, Kansal R, Bartels SR, Hamilton DJ, Shaaban S, Fleckenstein JM. Adhesin degradation accelerates delivery of heat-labile toxin by Enterotoxigenic Escherichia coli. J Biol Chem. 2011;286(34):29771-9. https://doi.org/10.1074/jbc. M111.251546.

58. Roy K, Hilliard GM, Hamilton DJ, Luo J, Ostmann MM, Fleckenstein JM. Enterotoxigenic Escherichia coli EtpA mediates adhesion between flagella and host cells. Nature. 2009;457(7229): 594-8. https://doi.org/10.1038/nature07568.

59. Kumar P, Kuhlmann FM, Bhullar K, Yang H, Vallance BA, Xia L, et al. Dynamic interactions of a conserved Enterotoxigenic Escherichia coli Adhesin with intestinal mucins govern epithelium engagement and toxin delivery. Infect Immun. 2016;84(12):3608 17. https://doi.org/10.1128/IAI.00692-16.

60. Arike L, Holmen-Larsson J, Hansson GC. Intestinal Muc2 mucin O-glycosylation is affected by microbiota and regulated by differential expression of glycosyltranferases. Glycobiology. 2017;27(4):318-28. https://doi.org/10.1093/glycob/cww134.

61. Kumar P, Kuhlmann FM, Chakroborty S, Bourgeois AL, FoulkeAbel J, Tumala B, et al. Enterotoxigenic Escherichia coli blood group a interactions intensify diarrheal severity. J Clin Invest. 2018;128:3298-311. https://doi.org/10.1172/JCI97659.

62. Kansal R, Rasko DA, Sahl JW, Munson GP, Roy K, Luo Q, et al. Transcriptional modulation of enterotoxigenic Escherichia coli virulence genes in response to epithelial cell interactions. Infect Immun. 2013;81(1):259-70. https://doi.org/10.1128/IAI.0091912.

63. Sheikh A, Rashu R, Begum YA, Kuhlman FM, Ciorba MA, Hultgren SJ, et al. Highly conserved type 1 pili promote enterotoxigenic E. coli pathogen-host interactions. PLoS Negl Trop Dis. 2017;11(5):e0005586. https://doi.org/10.1371/journal.pntd. 0005586 .

64. Sheikh A, Luo Q, Roy K, Shabaan S, Kumar P, Qadri F, et al. Contribution of the highly conserved EaeH surface protein to enterotoxigenic Escherichia coli pathogenesis. Infect Immun. 2014;82(9):3657-66. https://doi.org/10.1128/IAI.01890-14.

65. Harris JA, Roy K, Woo-Rasberry V, Hamilton DJ, Kansal R, Qadri F, et al. Directed evaluation of enterotoxigenic Escherichia coli autotransporter proteins as putative vaccine candidates. PLoS Negl Trop Dis. 2011;5(12):e1428. https://doi.org/10.1371/journal. pntd.0001428.

66. Luo Q, Kumar P, Vickers TJ, Sheikh A, Lewis WG, Rasko DA, et al. Enterotoxigenic Escherichia coli secretes a highly conserved mucin-degrading metalloprotease to effectively engage intestinal epithelial cells. Infect Immun. 2014;82(2):509-21. https://doi.org/ 10.1128/IAI.01106-13.

67. Dorsey FC, Fischer JF, Fleckenstein JM. Directed delivery of heatlabile enterotoxin by enterotoxigenic Escherichia coli. Cell Microbiol. 2006;8(9):1516-27. https://doi.org/10.1111/j.14625822.2006.00736.x.

68. Vicente AC, Teixeira LF, Iniguez-Rojas L, Luna MG, Silva L, Andrade JR, et al. Outbreaks of cholera-like diarrhoea caused by enterotoxigenic Escherichia coli in the Brazilian Amazon rainforest. Trans R Soc Trop Med Hyg. 2005;99(9):669-74.

69. Dutta S, Pazhani GP, Nataro JP, Ramamurthy T. Heterogenic virulence in a diarrheagenic Escherichia coli: evidence for an EPEC expressing heat-labile toxin of ETEC. Int J Med Microbiol. 2015;305(1):47-54. https://doi.org/10.1016/j.ijmm.2014.10.006.

70. Nyholm O, Halkilahti J, Wiklund G, Okeke U, Paulin L, Auvinen $\mathrm{P}$, et al. Comparative genomics and characterization of hybrid Shigatoxigenic and Enterotoxigenic Escherichia coli (STEC/ETEC) strains. PLoS One. 2015;10(8):e0135936. https:// doi.org/10.1371/journal.pone.0135936.

71. Investigators M-EN. The MAL-ED study: a multinational and multidisciplinary approach to understand the relationship between enteric pathogens, malnutrition, gut physiology, physical growth, cognitive development, and immune responses in infants and children up to 2 years of age in resource-poor environments. Clin 
Infect Dis. 2014;59(Suppl 4):S193-206. https://doi.org/10.1093/ cid/ciu653.

72. Kosek MN, Investigators M-EN. Causal pathways from Enteropathogens to environmental enteropathy: findings from the MAL-ED birth cohort study. EBioMedicine. 2017;18:10917. https://doi.org/10.1016/j.ebiom.2017.02.024.

73. Connor BA. Sequelae of traveler's diarrhea: focus on postinfectious irritable bowel syndrome. Clin Infect Dis. 2005;41(Suppl 8):S577-86. https://doi.org/10.1086/432956.

74. DuPont AW. Postinfectious irritable bowel syndrome. Clin Infect Dis. 2008;46(4):594-9. https://doi.org/10.1086/526774.

75. Ghoshal UC, Gwee KA. Post-infectious IBS, tropical sprue and small intestinal bacterial overgrowth: the missing link. Nat Rev Gastroenterol Hepatol. 2017;14(7):435-41. https://doi.org/10. 1038/nrgastro.2017.37.

76. Okhuysen PC, Jiang ZD, Carlin L, Forbes C, DuPont HL. Postdiarrhea chronic intestinal symptoms and irritable bowel syndrome in north American travelers to Mexico. Am J Gastroenterol. 2004;99(9):1774-8. https://doi.org/10.1111/j. 1572-0241.2004.30435.x.

77. Klem F, Wadhwa A, Prokop LJ, Sundt WJ, Farrugia G, Camilleri $\mathrm{M}$, et al. Prevalence, risk factors, and outcomes of irritable bowel syndrome after infectious enteritis: a systematic review and metaanalysis. Gastroenterology. 2017;152(5):1042-54. https://doi.org/ 10.1053/j.gastro.2016.12.039.

78. Schwille-Kiuntke J, Mazurak N, Enck P. Systematic review with meta-analysis: post-infectious irritable bowel syndrome after travellers' diarrhoea. Aliment Pharmacol Ther. 2015;41(11):1029-37. https://doi.org/10.1111/apt.13199.

79. Stermer E, Lubezky A, Potasman I, Paster E, Lavy A. Is traveler's diarrhea a significant risk factor for the development of irritable bowel syndrome? A prospective study. Clin Infect Dis. 2006;43(7):898-901. https://doi.org/10.1086/507540.

80. Nair P, Okhuysen PC, Jiang ZD, Carlin LG, Belkind-Gerson J, Flores J, et al. Persistent abdominal symptoms in US adults after short-term stay in Mexico. J Travel Med. 2014;21(3):153-8. https://doi.org/10.1111/jtm.12114.

81. Dupont HL. Gastrointestinal infections and the development of irritable bowel syndrome. Curr Opin Infect Dis. 2011;24(5):5038. https://doi.org/10.1097/QCO.0b013e32834a962d.

82. Harvey RF, Mauad EC, Brown AM. Prognosis in the irritable bowel syndrome: a 5-year prospective study. Lancet. 1987;1(8539):963-5.

83. Neal KR, Barker L, Spiller RC. Prognosis in post-infective irritable bowel syndrome: a six year follow up study. Gut. 2002;51(3): 410-3.

84. Hillary W, Hillary W. Observations on the changes of the air and the concomitant epidemical diseases, in the island of Barbados. To which is added A treatise on the putrid bilious fever, commonly called the yellow fever; and such other diseases as are indigenous or endemial, in the West India Islands, or in the Torrid Zone. London,: C. Hitch and L. Hawes; 1759. 8 , 360, 4 p. p.

85. Manson P. Imperial Maritime Customs II-special series 2. Medical reports for the first half year ended 31st March 188-0. 19th issue. Shanghai: Statistical department of the Inspectorate General 1880. 1880 .

86. Cook GC. Aetiology and pathogenesis of postinfective tropical malabsorption (tropical sprue). Lancet. 1984;1(8379):721-3.

87. Ghitis J, Tripathy K, Mayoral G. Malabsorption in the tropics. 2. Tropical sprue versus primary protein malnutrition: vitamin B12 and folic acid studies. Am J Clin Nutr. 1967;20(11):1206-11. https://doi.org/10.1093/ajcn/20.11.1206.

88. Klipstein FA. Tropical sprue in travelers and expatriates living abroad. Gastroenterology. 1981;80(3):590-600
89. Klipstein FA, Falaiye JM. Tropical sprue in expatriates from the tropics living in the continental United States. Medicine (Baltimore). 1969;48(6):475-91.

90. Lindenbaum J, Gerson CD, Kent TH. Recovery of small-intestinal structure and function after residence in the tropics. I. Studies in peace corps volunteers. Ann Intern Med. 1971;74(2):218-22.

91. Klipstein FA, Holdeman LV, Corcino JJ, Moore WE. Enterotoxigenic intestinal bacteria in tropical sprue. Ann Intern Med. 1973;79(5):632-41.

92. Klipstein FA, Samloff IM, Schenk EA. Tropical sprue in Haiti. Ann Intern Med. 1966;64(3):575-94.

93. Klipstein FA, Engert RF, Short HB. Enterotoxigenicity of colonising coliform bacteria in tropical sprue and blind-loop syndrome. Lancet. 1978;2(8085):342-4.

94. Sharma P, Baloda V, Gahlot GP, Singh A, Mehta R, Vishnubathla $\mathrm{S}$, et al. Clinical, endoscopic, and histological differentiation between celiac disease and tropical sprue: a systematic review. J Gastroenterol Hepatol. 2018. https://doi.org/10.1111/jgh.14403.

95. Falkow S. Molecular Koch's postulates applied to bacterial pathogenicity-a personal recollection 15 years later. Nat Rev Microbiol. 2004;2(1):67-72. https://doi.org/10.1038/nrmicro799.

96. Walker MM. What is tropical sprue? J Gastroenterol Hepatol. 2003;18(8):887-90.

97. Mathan VI. Tropical sprue in southern India. Trans R Soc Trop Med Hyg. 1988;82(1):10-4

98. Naylor C, Lu M, Haque R, Mondal D, Buonomo E, Nayak U, et al. Environmental enteropathy, Oral vaccine failure and growth faltering in infants in Bangladesh. EBioMedicine. 2015;2(11): 1759-66. https://doi.org/10.1016/j.ebiom.2015.09.036.

99. Keusch GT, Denno DM, Black RE, Duggan C, Guerrant RL, Lavery JV, et al. Environmental enteric dysfunction: pathogenesis, diagnosis, and clinical consequences. Clin Infect Dis. 2014;59(Suppl 4):S207-12. https://doi.org/10.1093/cid/ciu485.

100. Church JA, Parker EP, Kosek MN, Kang G, Grassly NC, Kelly P, et al. Exploring the relationship between environmental enteric dysfunction and oral vaccine responses. Future Microbiol. 2018;13:1055-70. https://doi.org/10.2217/fmb-2018-0016.

101. Watanabe K, Petri WA Jr. Environmental enteropathy: elusive but significant subclinical abnormalities in developing countries. EBioMedicine. 2016;10:25-32. https://doi.org/10.1016/j.ebiom. 2016.07.030.

102. Niehaus MD, Moore SR, Patrick PD, Derr LL, Lorntz B, Lima AA, et al. Early childhood diarrhea is associated with diminished cognitive function 4 to 7 years later in children in a northeast Brazilian shantytown. Am J Trop Med Hyg. 2002;66(5):590-3.

103. Scrimshaw NS, Taylor CE, Gordon JE. Interactions of nutrition and infection. Monogr Ser World Health Organ. 1968;57:3-329.

104. Black RE, Brown KH, Becker S. Malnutrition is a determining factor in diarrheal duration, but not incidence, among young children in a longitudinal study in rural Bangladesh. Am J Clin Nutr. 1984;39(1):87-94. https://doi.org/10.1093/ajcn/39.1.87.

105. Mondal D, Haque R, Sack RB, Kirkpatrick BD, Petri WA Jr. Attribution of malnutrition to cause-specific diarrheal illness: evidence from a prospective study of preschool children in Mirpur, Dhaka. Bangladesh Am J Trop Med Hyg. 2009;80(5):824-6.

106.• Platts-Mills JA, Taniuchi M, Uddin MJ, Sobuz SU, Mahfuz M, Gaffar SA, et al. Association between enteropathogens and malnutrition in children aged 6-23 mo in Bangladesh: a case-control study. Am J Clin Nutr. 2017;105(5):1132-8. https://doi.org/10. 3945/ajen.116.138800 Association of LT-ETEC and malnutrition.

107. Rogawski ET, Liu J, Platts-Mills JA, Kabir F, Lertsethtakarn P, Siguas M, et al. Use of quantitative molecular diagnostic methods to investigate the effect of enteropathogen infections on linear growth in children in low-resource settings: longitudinal analysis of results from the MAL-ED cohort study. Lancet Glob Health. 
2018;6(12):e1319-e28. https://doi.org/10.1016/S2214-109X(18) 30351-6.

108. Investigators M-EN. Early childhood cognitive development is affected by interactions among illness, diet, enteropathogens and the home environment: findings from the MAL-ED birth cohort study. BMJ Glob Health. 2018;3(4):e000752. https://doi.org/10. 1136/bmjgh-2018-000752.

109. Vonaesch P, Morien E, Andrianonimiadana L, Sanke H, Mbecko JR, Huus KE, et al. Stunted childhood growth is associated with decompartmentalization of the gastrointestinal tract and overgrowth of oropharyngeal taxa. Proc Natl Acad Sci U S A. 2018;115:E8489-98. https://doi.org/10.1073/pnas.1806573115.

110. Bourgeois AL, Wierzba TF, Walker RI. Status of vaccine research and development for enterotoxigenic Escherichia coli. Vaccine. 2016;34(26):2880-6. https://doi.org/10.1016/j.vaccine.2016.02. 076 Summary of current state of ETEC vaccine research.

111. Ahmed T, Bhuiyan TR, Zaman K, Sinclair D, Qadri F. Vaccines for preventing enterotoxigenic Escherichia coli (ETEC) diarrhoea. Cochrane Database Syst Rev. 2013;7:CD009029. https://oi.org/ 10.1002/14651858.CD009029.pub2.

112. Walker RI, Wierzba TF, Mani S, Bourgeois AL. Vaccines against Shigella and enterotoxigenic Escherichia coli: A summary of the 2016 VASE Conference. Vaccine. 2017;35(49 Pt A):6775-82. https://doi.org/10.1016/j.vaccine.2017.09.045.

113. Clemens JD, Sack DA, Harris JR, Chakraborty J, Neogy PK, Stanton B, et al. Cross-protection by B subunit-whole cell cholera vaccine against diarrhea associated with heat-labile toxin-producing enterotoxigenic Escherichia coli: results of a large-scale field trial. J Infect Dis. 1988;158(2):372-7.

114. Scerpella EG, Sanchez JL, Mathewson IJ, Torres-Cordero JV, Sadoff JC, Svennerholm AM, et al. Safety, immunogenicity, and protective efficacy of the whole-cell/recombinant B subunit (WC/ rBS) Oral cholera vaccine against Travelers' diarrhea. J Travel Med. 1995;2(1):22-7.

115. Lopez-Gigosos R, Campins M, Calvo MJ, Perez-Hoyos S, DiezDomingo J, Salleras L, et al. Effectiveness of the WC/rBS oral cholera vaccine in the prevention of traveler's diarrhea: a prospective cohort study. Hum Vaccin Immunother. 2013;9(3):692-8.

116. Peltola H, Siitonen A, Kyronseppa H, Simula I, Mattila L, Oksanen P, et al. Prevention of travellers' diarrhoea by oral Bsubunit/whole-cell cholera vaccine. Lancet. 1991;338(8778): 1285-9.

117. Rasko DA, Rosovitz MJ, Myers GS, Mongodin EF, Fricke WF, Gajer P, et al. The pangenome structure of Escherichia coli: comparative genomic analysis of E. coli commensal and pathogenic isolates. J Bacteriol. 2008;190(20):6881-93. https://doi.org/10. 1128/JB.00619-08.

118. von Mentzer A, Tobias J, Wiklund G, Nordqvist S, Aslett M, Dougan $\mathrm{G}$, et al. Identification and characterization of the novel colonization factor CS30 based on whole genome sequencing in enterotoxigenic Escherichia coli (ETEC). Sci Rep. 2017;7(1): 12514. https://doi.org/10.1038/s41598-017-12743-3.

119. Lundgren A, Bourgeois L, Carlin N, Clements J, Gustafsson B, Hartford M, et al. Safety and immunogenicity of an improved oral inactivated multivalent enterotoxigenic Escherichia coli (ETEC) vaccine administered alone and together with dmLT adjuvant in a double-blind, randomized, placebo-controlled phase I study. Vaccine. 2014;32(52):7077-84. https://doi.org/10.1016/j.vaccine. 2014.10.069.

120. Darsley MJ, Chakraborty S, Denearing B, Sack DA, Feller A, Buchwaldt C, et al. ACE527 Oral, live attenuated ETEC vaccine reduces the incidence and severity of diarrhea in a human challenge model of diarrheal disease. Clin Vaccine Immunol. 2012;19: 1921-31. https://doi.org/10.1128/CVI.00364-12.
121. Sahl JW, Steinsland H, Redman JC, Angiuoli SV, Nataro JP, Sommerfelt H, et al. A comparative genomic analysis of diverse clonal types of enterotoxigenic Escherichia coli reveals pathovarspecific conservation. Infect Immun. 2011;79(2):950-60. https:/ doi.org/10.1128/IAI.00932-10.

122. Luo Q, Qadri F, Kansal R, Rasko DA, Sheikh A, Fleckenstein JM. Conservation and immunogenicity of novel antigens in diverse isolates of enterotoxigenic Escherichia coli. PLoS Negl Trop Dis. 2015;9(1):e0003446. https://doi.org/10.1371/journal.pntd. 0003446.

123. Chakraborty S, Randall A, Vickers TJ, Molina D, Harro CD, DeNearing B, et al. Human experimental challenge with enterotoxigenic Escherichia coli elicits immune responses to canonical and novel antigens relevant to vaccine development. J Infect Dis. 2018;218:1436-46. https://doi.org/10.1093/infdis/jiy312.

124. Ward JI, Cherry JD, Chang SJ, Partridge S, Lee H, Treanor J, et al. Efficacy of an acellular pertussis vaccine among adolescents and adults. N Engl J Med. 2005;353(15):1555-63. https://doi.org/10. 1056/NEJMoa050824

125. Taranger J, Trollfors B, Bergfors E, Knutsson N, Lagergard T, Schneerson R, et al. Immunologic and epidemiologic experience of vaccination with a monocomponent pertussis toxoid vaccine. Pediatrics. 2001;108(6):E115.

126. Clements JD, Norton EB. The Mucosal Vaccine Adjuvant LT(R192G/L211A) or dmLT. mSphere. 2018;3(4). https://doi. org/10.1128/mSphere.00215-18.

127. Fleckenstein J, Sheikh A, Qadri F. Novel antigens for enterotoxigenic Escherichia coli vaccines. Expert Rev Vaccines. 2014;13(5): 631-9. https://doi.org/10.1586/14760584.2014.905745.

128. Fleckenstein JM. Providing structure to Enterotoxigenic Escherichia coli vaccine development. J Infect Dis. 2017;216(1):1-3. https://doi.org/10.1093/infdis/jix146.

129. Holmgren J, Bourgeois L, Carlin N, Clements J, Gustafsson B, Lundgren A, et al. Development and preclinical evaluation of safety and immunogenicity of an oral ETEC vaccine containing inactivated E. coli bacteria overexpressing colonization factors CFA/I, CS3, CS5 and CS6 combined with a hybrid LT/CT B subunit antigen, administered alone and together with dmLT adjuvant. Vaccine. 2013;31(20):2457-64. https://doi.org/10.1016/j. vaccine.2013.03.027.

130. Behrens RH, Cramer JP, Jelinek T, Shaw H, von Sonnenburg F, Wilbraham D, et al. Efficacy and safety of a patch vaccine containing heat-labile toxin from Escherichia coli against travellers' diarrhoea: a phase 3, randomised, double-blind, placebocontrolled field trial in travellers from Europe to Mexico and Guatemala. Lancet Infect Dis. 2013;14:197-204. https://doi.org/ 10.1016/S1473-3099(13)70297-4.

131. Walker R, Dull P. Combination vaccine strategies to prevent enteric infections. Vaccine. 2017;35(49 Pt A):6790-2. https://doi. org/10.1016/j.vaccine.2017.06.076.

132. Laird RM, Ma Z, Dorabawila N, Pequegnat B, Omari E, Liu Y, et al. Evaluation of a conjugate vaccine platform against enterotoxigenic Escherichia coli (ETEC), campylobacter jejuni and Shigella. Vaccine. 2018;36(45):6695-702. https://doi.org/10. 1016/j.vaccine.2018.09.052.

133. Barry EM, Altboum Z, Losonsky G, Levine MM. Immune responses elicited against multiple enterotoxigenic Escherichia coli fimbriae and mutant LT expressed in attenuated Shigella vaccine strains. Vaccine. 2003;21(5-6):333-40.

134. Barry EM, Wang J, Wu T, Davis T, Levine MM. Immunogenicity of multivalent Shigella-ETEC candidate vaccine strains in a Guinea pig model. Vaccine. 2006;24(18):3727-34. https://doi. org/10.1016/j.vaccine.2005.07.013. 